Article

\title{
Impact of Cellulase and Lactic Acid Bacteria Inoculant to Modify Ensiling Characteristics and In Vitro Digestibility of Sweet Corn Stover and Cassava Pulp Silage
}

\author{
Chatchai Kaewpila ${ }^{1}\left(\mathbb{D}\right.$, Suwit Thip-uten ${ }^{2}$, Anusorn Cherdthong ${ }^{3, *(D)}$ and Waroon Khota ${ }^{3, *}$ \\ 1 Faculty of Natural Resources, Rajamangala University of Technology Isan, Sakon Nakhon 47160, Thailand; \\ c_kaewpila@yahoo.com \\ 2 Faculty of Agricultural Technology, Sakon Nakhon Rajabhat University, Sakon Nakhon 47000, Thailand; \\ suwit@snru.ac.th \\ 3 Faculty of Agriculture, Khon Kaen University, Khon Kaen 40002, Thailand \\ * Correspondence: anusornc@kku.ac.th (A.C.); w_khota@hotmail.com (W.K.); \\ Tel.: +66-43-202-362 (A.C. \& W.K.)
}

check for updates

Citation: Kaewpila, C.; Thip-uten, S.; Cherdthong, A.; Khota, W. Impact of Cellulase and Lactic Acid Bacteria Inoculant to Modify Ensiling Characteristics and In Vitro Digestibility of Sweet Corn Stover and Cassava Pulp Silage. Agriculture 2021, 11, 66. https://doi.org/ 10.3390/agriculture11010066

Received: 17 December 2020 Accepted: 11 January 2021 Published: 15 January 2021

Publisher's Note: MDPI stays neutral with regard to jurisdictional clai$\mathrm{ms}$ in published maps and institutional affiliations.

Copyright: (C) 2021 by the authors. Licensee MDPI, Basel, Switzerland. This article is an open access article distributed under the terms and conditions of the Creative Commons Attribution (CC BY) license (https:// creativecommons.org/licenses/by/ $4.0 /)$.

\begin{abstract}
Improving the productive performance of agricultural residue silage has practical relevance to sustaining livestock production. Sweet corn stover (SCS) and cassava pulp (CSVP) are widespread in the tropics as low-cost feed resources. To efficiently prepare SCS and CSVP silage, the impact of adding Acremonium cellulase (AC), Lactobacillus casei strain TH14 inoculant (TH14), and their combination (AC+TH14) on ensiling characteristics, microbial population, chemical compositions, and in vitro digestibility were tested in comparison to control (no additive). After $60 \mathrm{~d}$ of ensiling, the $\mathrm{pH}$ value and ammonia nitrogen content of silage were lower $(p<0.05)$ when AC was used as the additive. Compared with other treatments, TH14 provided abundant lactic acid fermentation in silage. All tested additives increased the crude protein $(\mathrm{CP})$ content and decreased the neutral detergent fiber (NDF) content of SCS silage. In CSVP silage, only AC and AC+TH14 altered the CP and NDF content. In addition, $\mathrm{AC}$ and $\mathrm{AC}+\mathrm{TH} 14$ provided greater in vitro dry matter digestibility and a lower in vitro fiber digestibility. Overall, optimized either AC or TH14 can be recommended as an attractive additive to improve the ensiling characteristics of SCS and CSVP silage. AC significantly modifies the in vitro digestibility of silage.
\end{abstract}

Keywords: sweet corn stover; cassava pulp; anaerobic fermentation; bacterial inoculation; enzyme; in vitro test

\section{Introduction}

Recovery and valorization of agro-industrial residues are currently indicated as key factors for the development of circular economy models and to promote the environmental sustainability of production systems [1]. Sweet corn (Zea mays L. var. rugose) stover (SCS) and cassava (Manihot esculenta Crantz) pulp (CSVP) are wet agricultural residues that have been used in the tropics and sub-tropics as low-cost feed resources [2]. In Thailand, ears of corn are harvested when the silks are dried and turning brown [3]. The remaining parts in the field are called SCS, of which annual production was about 0.3 million tons fresh matter (FM) or about 32\% of the weight of the original corn plants [3]. SCS is a good source of plant fiber because it has high neutral detergent fiber (NDF) content of about $700 \mathrm{~g} \mathrm{~kg}^{-1}$ on a dry matter (DM) basis [4]. CSVP is a byproduct of cassava root starch production. Annual CSVP production was estimated at 1 million tons of FM, or about $10-30 \%$ of the weight of the original tubers [5]. For CSVP, the NDF content is low $\left(350 \mathrm{~g} \mathrm{~kg}^{-1} \mathrm{DM}\right)$ but it has a high non-fiber carbohydrate (NFC) content of about $600 \mathrm{~g} \mathrm{~kg}^{-1} \mathrm{DM}$ [6].

For preservation purposes, the plant materials including agricultural residues are usually preserved as silage [7]. Studies of silage additives, including both chemical and biological compounds, have been highlighting improved silage potential feedstock for the 
production of biochemical, biogas, bio-ethanol, and feedstuffs $[4,6,8,9]$. Regarding the use of silage in animal feeding, Driehuis et al. [10] stated that silage quality is important so as to avoid the presence of pathogens and undesirable end-products. Cellulase enzyme is a biotechnology used to improve the ensiling characteristics for subsequent utilization of tropical feed resources [11]. As reported by Kaewpila et al. [12], an optimized cellulase enzyme can provide the saccharification effect to satiate lactic acid fermentation and enhance nutritional parameters from plant fiber degradation. In addition, local lactic acid bacteria (LAB) strains from various bio-resources have been increasingly selected to enhance the practical silage production $[13,14]$. The use of LAB inoculant as a natural probiotic to enhance lactic acid fermentation (reducing $\mathrm{pH}$ value) in silage is a good strategy. Moreover, Li et al. [15] recently implied that some LAB strains might also help to reduce the lignin content (delignification) in silage when inoculated with a cellulase enzyme. In previous studies, Lactobacillus casei strain TH14 (TH14) was verified as the most effective LAB strain compared with several representative strains for improving fermentation quality and nutritive value of tropical silage [16,17]. This strain was isolated from corn stover silage [18]. According to Pholsen et al. [18], TH14 is homofermentative rod, produces D-lactate, and could play an important role in promoting lactic acid production for a longer time during silage fermentation.

Presently, the study of the additives or factors associated with improved performance of SCS and CSVP silage for subsequent supporting ruminant production in the Indochinese Peninsular is an important step that would provide information on a little explored topic $[4,6]$. Thus, the objective of this study was to evaluate the ensiling characteristics, microbial population, chemical composition, and in vitro digestibility of SCS and CSVP silage inoculated with cellulase enzyme, TH14 inoculant, and a combination of both.

\section{Materials and Methods}

\subsection{Material Preparation}

Both SCS and CSVP materials were obtained in Khon Kaen, Thailand $\left(16^{\circ} 26^{\prime} \mathrm{N}\right.$, $\left.102^{\circ} 48^{\prime} \mathrm{W}\right)$. Fresh SCS was purchased from a single plot of sweet corn growth ( 0.8 hectare and 75 to $85 \mathrm{~d}$ of growth). Sixteen sub-plots of SCS were established using quadrate samplers $(10 \times 10 \mathrm{~m}$ ). The SCS containing discarded ears (about 40 to $50 \mathrm{~kg} \mathrm{FM}$ ) was cut close to the soil surface. The samples of SCS were immediately transported to the experimental location (within $2 \mathrm{~h}$ ), chopped individually in pieces of $1 \mathrm{~cm}$ using a forage chopper, mixed homogeneously, and separated into two portions. One portion (16 sub-plots $\times 1 \mathrm{~kg} \mathrm{FM})$ was obtained, pooled, and collected ( $1 \mathrm{~kg} \mathrm{FM}$ ) for measuring microbial population, chemical composition, and gross energy (GE) content. The other portion (16 sub-plots $\times 35 \mathrm{~kg} \mathrm{FM})$ was placed on a $4 \times 4 \mathrm{~m}$ polyethylene sheet for silage making.

Fresh CSVP (moist cake of ivory color) was delivered from four local suppliers (in total 4.4 tons of fresh weight). This material was not chopped because it came as a cake [6]. The CSVP was then divided into sixteen parts of $36 \mathrm{~kg} \mathrm{FM}$; and each part was separated into two portions ( $1 \mathrm{~kg}$ FM and $35 \mathrm{~kg} \mathrm{FM})$. All portions were processed similarly to what was described for SCS.

\subsection{Experimental Design and Silage Preparation}

We used a completely randomized design to evaluate the individual materials with different additives. SCS and CSVP were untreated (control) or treated with cellulase enzyme $0.1 \mathrm{~g} \mathrm{~kg}^{-1} \mathrm{FM}(\mathrm{AC}), \mathrm{LAB}$ inoculant $1 \times 10^{8}$ colony forming units (cfu) $\mathrm{kg}^{-1} \mathrm{FM}$ (TH14), or their combination (AC+TH14). The quantity of additives used was estimated to be a modest dosage to improve tropical grass silage quality according to Khota et al. [11,16]. A commercial cellulase enzyme (glucanase and pectinase $7350 \mathrm{U} \mathrm{g}^{-1}$ ) produced from Acremonium cellulolyticus was used [11]. Briefly, to increase the fermentable sugars during ensiling, addition of AC was recommended at $0.1 \mathrm{~g} \mathrm{~kg}^{-1} \mathrm{FM} \mathrm{[11].} \mathrm{Inoculation} \mathrm{of} \mathrm{strain}$ TH14 for ensuring lactic acid production was optimized at $1.0 \times 10^{8} \mathrm{cfu} \mathrm{kg}^{-1} \mathrm{FM} \mathrm{[18].}$ For every $35 \mathrm{~kg}$ of fresh material, each additive was pre-prepared as a $35 \mathrm{~mL}$ suspension. 
The AC (3.5 g) was dissolved with $35 \mathrm{~mL}$ of sterilized distilled water. Strain TH14 was cultured overnight in Lactobacilli de Man, Rogosa, Sharpe (MRS) broth (Difco Laboratories, Detroit, MI, USA) at $30{ }^{\circ} \mathrm{C}$. The TH14 was then diluted with $0.85 \%$ sodium chloride solution to spread in a $1.0 \times 10^{8} \mathrm{cfu} \mathrm{mL}^{-1}$ of suspension [16]. The materials were sprayed by the additive, mixed homogeneously, and manually packed into pre-weighted polyethylene drum cans ( $35 \mathrm{~L}$ capacity). The packable materials were sealed with lids and weighted. The final densities of material in the hermetic cans were 778 and $1000 \mathrm{~kg} \mathrm{FM} \mathrm{per} \mathrm{m}^{3}$ for SCS and CSVP, respectively. For each material, four silos per treatment were prepared. Silos were stored indoors for $60 \mathrm{~d}$ until the stable phase was reached [19]. No leakage of fermented liquid was observed. The silage was removed from silo, mixed homogeneously, and collected ( 2 materials $\times 4$ additives $\times 4$ silos $\times 1 \mathrm{~kg} \mathrm{FM}$ ) for analysis of microbial population, fermentation characteristics, chemical composition, GE content, and in vitro digestibility.

\subsection{Microbial Counting}

The samples of fresh materials and silage were analyzed for LAB, coliform bacteria, aerobic bacteria, yeast, and mold populations using the plate counting methods described previously [12,16], according to the original procedure by Kozaki et al. [20]. Each sample was then analyzed in triplicate. A $10 \mathrm{~g}$ sample was blended with $90 \mathrm{~mL}$ of sterile $0.85 \%$ sodium chloride solution and serial dilutions at $10^{-1}$ to $10^{-5}$. Each dilution $(20 \mu \mathrm{L})$ was spread on agar plates and cultured at $30^{\circ} \mathrm{C}$. LAB was counted on MRS agar (Difco) after $48 \mathrm{~h}$ of incubation in an anaerobic box (Sugiyamagen Ltd., Tokyo, Japan). Coliform bacteria were counted on blue-light broth agar (Nissui-seiyaku Ltd., Tokyo, Japan) after $2 \mathrm{~d}$ of incubation. Aerobic bacteria were counted on nutrient agar (Difco) after $3 \mathrm{~d}$ of incubation. Yeast and mold were counted on potato dextrose agar (Nissui-seiyaku) after $7 \mathrm{~d}$ and $2 \mathrm{~d}$ of incubation, respectively. Yeasts were distinguished from mold or bacteria by colony appearance and cell morphology observation. The counts were reported as $\mathrm{cfu} \mathrm{g}^{-1} \mathrm{FM}$.

\subsection{Chemical Composition, and Gross Energy Content Analyses}

The DM content was examined by drying at $100{ }^{\circ} \mathrm{C}$ for $24 \mathrm{~h}$. The samples for chemical analyses were prepared by drying at $60{ }^{\circ} \mathrm{C}$ for $48 \mathrm{~h}$. They were ground to pass through a $1 \mathrm{~mm}$ screen and the organic matter $(\mathrm{OM})$, crude protein $(\mathrm{CP})$, and ether extract (EE) contents were analyzed following the standard Association of Official Analytical Chemists [21] methods 942.05, 976.05, and 920.39, respectively. The NDF and acid detergent fiber (ADF) contents were analyzed using a fiber analyzer (ANKOM 200, ANKOM Technology, Macedon, NY, USA) based on the manufacturer's recommendations. The acid detergent lignin (ADL) was measured by solubilization with a sulfuric acid solution following the method of Faichney and White [22]. The NFC content of pre-ensiled materials was calculated as DM minus ash, $\mathrm{CP}, \mathrm{EE}$, and NDF components [23]. The GE was analyzed via an automatic adiabatic bomb calorimeter (AC500 Isoperibol Calorimeter, LECO Corp., St. Joseph, MI, USA).

\subsection{Fermentation End Product Analysis of Silage}

A $10 \mathrm{~g}$ sample was mixed with $90 \mathrm{~mL}$ sterilized distilled water and incubated at $4{ }^{\circ} \mathrm{C}$ for $12 \mathrm{~h}$ [24]. The $\mathrm{pH}$ value was then measured via a glass electrode $\mathrm{pH}$ meter (FiveGo, Mettler-Toledo GmbH, Greifensee, Switzerland). The concentrations of lactic acid, acetic acid, propionic acid, and butyric acid were measured using a gas chromatograph (Nexis GC-2030: SHIMADZU, Shimadzu Corp., Kyoto, Japan) equipped with a capillary column (molecular sieve 13X, 30/60 mesh, Alltech Associates Inc., Deerfield, IL, USA) as described previously [25]. The ammonia nitrogen $\left(\mathrm{NH}_{3}-\mathrm{N}\right)$ content was determined using a spectrophotometer (UV/VIS Spectrometer, PG Instruments Ltd., London, United Kingdom) based on the method of Fawcett and Scott [26]. 


\subsection{In Vitro Rumen Digestibility Analysis of Silage}

The ground silage samples were measured for in vitro DM digestibility (IVDMD), in vitro NDF digestibility (IVNDFD), and in vitro ADF digestibility (IVADFD) at $24 \mathrm{~h}$ and $48 \mathrm{~h}$ after incubation using an in vitro rumen fluid gas production technique according to the method described by Makkar et al. [27]. The rumen fluid was collected before morning feeding from four Zebu beef cattle (body weight $=299 \pm 21 \mathrm{~kg}$ ) by a stomachtube sucker. The daily diet of the cattle was a basal total mixed ration containing $500 \mathrm{~g}$ $\mathrm{kg}^{-1}$ rice straw, $300 \mathrm{~g} \mathrm{~kg}^{-1}$ cassava chips, $100 \mathrm{~g} \mathrm{~kg}^{-1}$ soybean meal, $90 \mathrm{~g} \mathrm{~kg}^{-1}$ rice bran, $5 \mathrm{~g} \mathrm{~kg}^{-1}$ mineral-premix, and $5 \mathrm{~g} \mathrm{~kg}^{-1}$ urea on a DM basis. Rumen fluid was filtered to pass through a four-layer cloth sheet into pre-warmed $\left(39^{\circ} \mathrm{C}\right)$ thermo bottles and was transported immediately to the laboratory. Rumen fluid was mixed with a mineral buffer solution [27] at a 1:4 ratio under a stream of carbon dioxide. The samples $(0.50 \mathrm{~g} \mathrm{DM})$ were precisely pre-weighed into $50 \mathrm{~mL}$ serum bottles, sealed with rubber stoppers and aluminum caps and pre-warmed in a water-bath checker (WNB22, Memmert GmbH + Co. KG, Schwabach, Germany). The rumen fluid-buffer mixture $(40 \mathrm{~mL})$ was injected into each sample bottle using $60 \mathrm{~mL}$ syringes with a 1.5 inch 18-gauge needle and was anaerobically flushed with carbon dioxide. Incubations were carried out in two batches for in vitro evaluations at $24 \mathrm{~h}$ or $48 \mathrm{~h}$ of incubation with different flasks of rumen inoculum. Within each batch, 99 bottles were incubated at $39^{\circ} \mathrm{C}$, corresponding to 2 materials $\times 4$ additives $\times 4$ silos $\times 3$ bottles plus 3 blanks. The blanks were bottles consisting of only rumen inoculum. The produced gas was leaked at $2 \mathrm{~h}$ intervals using a 21-gauge needle. After incubation the bottles were opened immediately. The residual particles were washed into filter bags (model F57; Ankom Technology, Macedon, NY, USA) using distilled water, dried at $100{ }^{\circ} \mathrm{C}$ in a forced air oven for $24 \mathrm{~h}$, and weighed for IVDMD determination [12]. The IVNDFD and IVADFD contents were measured after being analyzed for the contents of residual NDF and ADF, respectively (ANKOM 200). For each material, each experimental unit was averaged from the three bottles minus blanks after every hour of incubation.

\subsection{Statistical Analysis}

The data were analyzed using an ANOVA procedure in SAS version 6.12 (SAS Institute Inc., Cary, NC, USA) with the following model:

$$
Y_{i j}=\mu+\alpha_{i}+\varepsilon_{i j}
$$

where $Y_{\mathrm{ijk}}=$ observation, $\mu$ = overall mean, $\alpha_{\mathrm{i}}=$ additive effect $(\mathrm{i}=1$ to 4$)$, and $\varepsilon_{\mathrm{ij}}=$ error. Significant differences among treatment means were assessed by Duncan's new multiple range test (DMRT) and the significance level was set at $p<0.05$ [28].

\section{Results}

\subsection{Microbial Counts, Chemical Composition, and Gross Energy Content of Ensiling Materials}

The microbial counts, chemical composition, and GE content of SCS and CSVP before ensiling are presented in Table 1 . The counts of LAB, coliform bacteria, and aerobic bacteria in SCS ranged from $10^{4}$ to $10^{5} \mathrm{cfu} \mathrm{g}^{-1} \mathrm{FM}$. The counts of yeasts and molds in SCS were less than $10^{2} \mathrm{cfu} \mathrm{g}^{-1} \mathrm{FM}$ (below the detectable level). For CSVP, the counts of LAB and aerobic bacteria were $10^{4} \mathrm{cfu} \mathrm{g}^{-1} \mathrm{FM}$, while the others were less than $10^{2} \mathrm{cfu} \mathrm{g}^{-1} \mathrm{FM}$. All chemical compositions and GE contents differed extremely between SCS and CSVP. The DM contents of SCS and CSVP were 237 and $187 \mathrm{~g} \mathrm{~kg}^{-1}$, respectively. The OM content of CSVP was very high $\left(977 \mathrm{~g} \mathrm{~kg}^{-1} \mathrm{DM}\right)$. The CP content of SCS was about four times that of CSVP. The NDF, ADF, and ADL contents were approximately twice as high in SCS than in CSVP. The NFC content of CSVP was high but its GE content was low. 
Table 1. Microbial counts, chemical composition, and gross energy content of pre-ensiled materials used in this study.

\begin{tabular}{ccc}
\hline Item $^{\mathbf{1}}$ & SCS & CSVP \\
\hline Microbial counts $\left(\mathrm{cfu} \mathrm{g}^{-1} \mathrm{FM}\right)$ & & \\
\hline LAB & $4.55 \times 10^{5}$ & $2.88 \times 10^{4}$ \\
Coliform bacteria & $3.74 \times 10^{4}$ & $\mathrm{ND}$ \\
Aerobic bacteria & $2.60 \times 10^{5}$ & $3.20 \times 10^{4}$ \\
Yeasts & $\mathrm{ND}$ & $\mathrm{ND}$ \\
Molds & $\mathrm{ND}$ & $\mathrm{ND}$ \\
\hline Chemical composition $\left(\mathrm{g} \mathrm{kg}^{-1} \mathrm{DM}\right)$ & & \\
\hline DM (g kg $\left.{ }^{-1}\right)$ & 236.5 & 187.4 \\
OM & 922.1 & 976.7 \\
CP & 92.1 & 19.6 \\
EE & 14.6 & 3.7 \\
NDF & 688.6 & 352.9 \\
ADF & 395.4 & 200.7 \\
ADL & 51.0 & 32.9 \\
NFC & 126.9 & 600.5 \\
\hline GE content (MJ kg & 17.25 & 15.94 \\
\hline
\end{tabular}

${ }_{1}^{1} \mathrm{cfu}$, colony forming unit; FM, fresh matter; LAB, lactic acid bacteria; DM, dry matter; OM, organic matter; $\mathrm{CP}$, crude protein; $\mathrm{EE}$, ether extract; NDF, neutral detergent fiber; $\mathrm{ADF}$, acid detergent fiber; $\mathrm{ADL}$, acid detergent lignin; NFC, nonfiber carbohydrates; GE, gross energy; SCS, sweet corn stover; CSVP, cassava pulp; $\mathrm{ND}$, not detected $\left(<10^{2} \mathrm{cfu} \mathrm{g}^{-1} \mathrm{FM}\right)$.

\subsection{Effect on Ensiling Characteristics}

The effects of additives on $\mathrm{pH}$, organic acid content, and $\mathrm{NH}_{3}-\mathrm{N}$ content of SCS and CSVP silage are shown in Table 2. For SCS silage, the $\mathrm{pH}$ values were lower $(p<0.05)$ with AC and TH14 addition compared with the control. For CSVP silage, the $\mathrm{pH}$ decreased significantly $(p<0.05)$ with all three additives used. The lactic acid content in both SCS and CSVP silage was improved $(p<0.05)$ by additives, except when AC was added to SCS silage. Adding AC+TH14 increased $(p=0.05)$ the acetic acid content of SCS silage but decreased $(p<0.05)$ that of CSVP silage. The contents of propionic acid and butyric acid of SCS silage tended to be higher $(p=0.09)$ in the control, followed by the additive treatments. However, these two organic acids of CSVP silage were not affected ( $p \geq 0.11)$ by the treatments. For SCS silage, AC addition significantly reduced $(p<0.05)$ the $\mathrm{NH}_{3}-\mathrm{N}$ content, while the other two additives did not. Compared with the control, the addition of AC, TH14, and AC+TH14 significantly decreased $(p<0.05)$ the $\mathrm{NH}_{3}-\mathrm{N}$ content in CSVP silage.

Table 2. Ensiling characteristics of silage after $60 \mathrm{~d}$ of fermentation.

\begin{tabular}{|c|c|c|c|c|c|c|c|}
\hline \multirow{2}{*}{ Item $^{1}$} & \multirow{2}{*}{ Additives } & \multirow{2}{*}{$\mathrm{pH}$} & Lactic Acid & Acetic Acid & Propionic Acid & Butyric Acid & $\mathrm{NH}_{3}-\mathrm{N}$ \\
\hline & & & \multicolumn{5}{|c|}{$\left(\mathrm{g} \mathrm{kg}^{-1} \mathrm{DM}\right)$} \\
\hline \multirow{6}{*}{ SCS silage } & Control & $3.87^{\mathrm{a}}$ & $91.8^{c}$ & $25.2^{b}$ & $2.14^{x}$ & $1.20^{\mathrm{y}}$ & $1.41^{\mathrm{a}}$ \\
\hline & $\mathrm{AC}$ & $3.81^{b}$ & $98.1^{b c}$ & $28.0^{\mathrm{ab}}$ & $1.26^{\mathrm{y}}$ & $0.13^{z}$ & $1.03^{b}$ \\
\hline & TH14 & $3.79^{b}$ & $114^{\mathrm{a}}$ & $23.3^{b}$ & $0.01^{\mathrm{z}}$ & $0.19^{z}$ & $1.45^{\mathrm{a}}$ \\
\hline & $\mathrm{AC}+\mathrm{TH} 14$ & $3.85^{\mathrm{ab}}$ & $103^{b}$ & $31.8^{\mathrm{a}}$ & $0.50 \mathrm{yz}$ & $0.27^{\mathrm{z}}$ & $1.39^{\mathrm{a}}$ \\
\hline & SEM & 0.017 & 2.79 & 1.83 & 0.542 & 0.289 & 0.058 \\
\hline & $p$ & 0.002 & 0.003 & 0.050 & 0.093 & 0.096 & 0.003 \\
\hline \multirow{6}{*}{$\begin{array}{l}\text { CSVP } \\
\text { silage }\end{array}$} & Control & $3.60^{\mathrm{a}}$ & $87.8^{b}$ & $92.2^{a b}$ & 2.64 & 0.64 & $0.28^{a}$ \\
\hline & $\mathrm{AC}$ & $3.42^{b}$ & $143^{a}$ & $80.7^{b c}$ & 0.41 & 0.07 & $0.13^{b}$ \\
\hline & TH14 & $3.49^{b}$ & $150^{a}$ & $98.7^{\mathrm{a}}$ & 1.30 & 0.31 & $0.16^{b}$ \\
\hline & $\mathrm{AC}+\mathrm{TH} 14$ & $3.42^{b}$ & $150^{a}$ & $72.8^{c}$ & 0.34 & 0.04 & $0.12^{b}$ \\
\hline & SEM & 0.027 & 7.67 & 4.14 & 0.962 & 0.174 & 0.025 \\
\hline & $p$ & 0.005 & 0.001 & 0.009 & 0.357 & 0.114 & 0.008 \\
\hline
\end{tabular}

${ }^{1}$ SCS, sweet corn stover; CSVP, cassava pulp; AC, Acremonium cellulase; TH14, L. casei strain TH14 inoculant; SEM, standard error of the means; $\mathrm{NH}_{3}-\mathrm{N}$, ammonia nitrogen; DM, dry matter. ${ }^{\mathrm{a}-\mathrm{c}}$ Means within columns with difference superscript letters differ at $p<0.05$. ${ }^{\mathrm{x}-\mathrm{z}}$ Mean separations, refer to the differences as tendencies $(p<0.10)$. 


\subsection{Effect on Microbial Population of Silage}

The microbial populations of SCS and CSVP silage at $60 \mathrm{~d}$ after fermentation are shown in Table 3. The LAB counts for SCS silage were $10^{7} \mathrm{cfu} \mathrm{g}^{-1} \mathrm{FM}$; there was no difference $(p=0.13)$ among the different treatments. For CSVP silage, the LAB population was significantly lower $(p<0.05)$ for AC+TH14 when compared with the control and TH14 treatment. Counts of aerobic bacteria in SCS silage were significantly higher $(p<0.05)$ for AC+TH14 in comparison with the control and other additives, but those in CSVP silage exhibited no significant difference $(p=0.30)$ among treatments. In all silage, the counts of coliform bacteria, yeasts, and molds decreased to below the detectable level $\left(<10^{2} \mathrm{cfu} \mathrm{g}^{-1} \mathrm{FM}\right)$.

Table 3. Microbial populations of silage after $60 \mathrm{~d}$ of fermentation.

\begin{tabular}{|c|c|c|c|c|c|c|}
\hline \multirow[t]{2}{*}{ Item $^{1}$} & \multirow[t]{2}{*}{ Additives } & LAB & $\begin{array}{l}\text { Coliform } \\
\text { Bacteria }\end{array}$ & $\begin{array}{l}\text { Aerobic } \\
\text { Bacteria }\end{array}$ & Yeasts & Molds \\
\hline & & \multicolumn{5}{|c|}{$\left(\mathrm{cfu} \mathrm{g}^{-1} \mathrm{FM}\right)$} \\
\hline \multirow{6}{*}{ SCS silage } & Control & $1.4 \times 10^{7}$ & ND & $1.5 \times 10^{3 b}$ & ND & ND \\
\hline & $\mathrm{AC}$ & $3.9 \times 10^{7}$ & ND & $1.8 \times 10^{3 b}$ & ND & ND \\
\hline & TH14 & $4.8 \times 10^{7}$ & ND & $1.2 \times 10^{3 b}$ & ND & ND \\
\hline & $\mathrm{AC}+\mathrm{TH} 14$ & $3.2 \times 10^{7}$ & ND & $3.5 \times 10^{3 \mathrm{a}}$ & ND & ND \\
\hline & SEM & 89.15 & - & 34.10 & - & - \\
\hline & $p$ & 0.130 & - & 0.007 & - & - \\
\hline \multirow{6}{*}{ CSVP silage } & Control & $9.8 \times 10^{6} \mathrm{ab}$ & ND & $1.1 \times 10^{3}$ & ND & ND \\
\hline & $\mathrm{AC}$ & $6.8 \times 10^{6} \mathrm{bc}$ & ND & $7.1 \times 10^{2}$ & ND & ND \\
\hline & TH14 & $1.4 \times 10^{7 \mathrm{a}}$ & ND & $1.8 \times 10^{3}$ & ND & ND \\
\hline & $\mathrm{AC}+\mathrm{TH} 14$ & $4.8 \times 10^{6 c}$ & ND & $1.2 \times 10^{3}$ & ND & ND \\
\hline & SEM & 13.17 & - & 37.11 & - & - \\
\hline & $p$ & 0.008 & - & 0.297 & - & - \\
\hline
\end{tabular}

${ }^{1}$ SCS, sweet corn stover; CSVP, cassava pulp; AC, Acremonium cellulase; TH14, L. casei strain TH14 inoculant; SEM, standard error of the means; LAB, lactic acid bacteria; cfu, colony forming unit; FM, fresh matter; ND, not detected $\left(<10^{2} \mathrm{cfu} \mathrm{g}^{-1} \mathrm{FM}\right){ }^{\mathrm{a}-\mathrm{c}}$ Means within columns with difference superscript letters differ at $p<0.05$.

\subsection{Effect on Chemical Composition and Gross Energy Content}

The DM and OM contents of SCS silage tended to differ $(p=0.07)$ among treatments (Table 4). In CSVP silage, although DM content did not differ $(p=0.33)$ among treatments, the OM content was significantly greater $(p<0.05)$ when it was added by AC or AC+TH14 additive. The CP content of both SCS and CSVP silage increased significantly $(p<0.05)$ using additives, except with the addition of TH14 to CSVP silage. The EE content of SCS silage was significantly lower $(p<0.05)$ for the TH14 additive and for CSVP silage it was significantly greater $(p<0.05)$ with the AC and AC+TH14 treatment compared with the control and the TH14 treatment. For SCS silage, the NDF content was significantly greater $(p<0.05)$ in the control, with slightly lower increases for the TH14, AC, and AC+TH14 treatments in decreasing order. In CSVP silage, the NDF content was significantly greater $(p<0.05)$ in the control and TH14 treatment, with the AC and AC+TH14 showing a smaller increase. In comparison with the control, the ADF content in SCS and CSVP silage decreased significantly $(p<0.05)$ with the use of additives. The ADL content of SCS silage was not affected $(p=0.60)$ by the additives. The addition of TH14 significantly reduced $(p<0.05)$ the ADL content of CSVP silage compared with the control and other additives. The GE content of SCS silage was significantly greater $(p<0.05)$ for the control and AC+TH14 treatment, but there was no difference $(p=0.89)$ in its content observed for CSVP silage. 
Table 4. Chemical composition and gross energy content of silage after $60 \mathrm{~d}$ of fermentation.

\begin{tabular}{|c|c|c|c|c|c|c|c|c|c|}
\hline \multirow{2}{*}{ Item $^{1}$} & \multirow{2}{*}{ Additives } & \multirow{2}{*}{$\begin{array}{c}\text { DM } \\
\left(\mathrm{g} \mathrm{kg}^{-1}\right)\end{array}$} & OM & $\mathrm{CP}$ & $\mathrm{EE}$ & NDF & ADF & ADL & \multirow{2}{*}{ 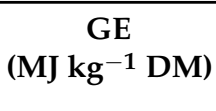 } \\
\hline & & & \multicolumn{6}{|c|}{$\left(\mathrm{g} \mathrm{kg}^{-1} \mathrm{DM}\right)$} & \\
\hline \multirow{6}{*}{ SCS silage } & Control & $219 \mathrm{y}$ & $923^{z}$ & $90.5^{b}$ & $17.7^{\mathrm{a}}$ & $687^{a}$ & $416^{\mathrm{a}}$ & 51.4 & $17.4^{\mathrm{a}}$ \\
\hline & $\mathrm{AC}$ & $203^{z}$ & $922^{z}$ & $95.9^{a}$ & $17.4^{\mathrm{ab}}$ & $640^{c}$ & $397^{b}$ & 50.7 & $17.3^{b}$ \\
\hline & TH14 & $202^{z}$ & $925 \mathrm{y}$ & $96.3^{a}$ & $14.7^{\mathrm{b}}$ & $655^{b}$ & $399^{b}$ & 51.0 & $17.1^{\mathrm{c}}$ \\
\hline & $\mathrm{AC}+\mathrm{TH} 14$ & $201^{z}$ & $923^{z}$ & $95.4^{\mathrm{a}}$ & $19.5^{\mathrm{a}}$ & $640^{c}$ & $391^{b}$ & 50.3 & $17.5^{\mathrm{a}}$ \\
\hline & SEM & 4.3 & 0.9 & 1.21 & 0.90 & 4.0 & 3.7 & 0.60 & 0.02 \\
\hline & $p$ & 0.057 & 0.067 & 0.030 & 0.032 & 0.001 & 0.007 & 0.603 & 0.001 \\
\hline \multirow{6}{*}{$\begin{array}{l}\text { CSVP } \\
\text { silage }\end{array}$} & Control & 118 & $970^{a}$ & $24.4^{\mathrm{b}}$ & $2.70^{c}$ & $356^{a}$ & $228^{a}$ & $37.0^{\mathrm{a}}$ & 16.1 \\
\hline & $\mathrm{AC}$ & 105 & $963^{b}$ & $29.4^{\mathrm{a}}$ & $4.70^{a b}$ & $185^{b}$ & $116^{\mathrm{c}}$ & $40.0^{\mathrm{a}}$ & 16.2 \\
\hline & TH14 & 115 & $971^{a}$ & $25.2^{b}$ & $3.85^{b c}$ & $357^{a}$ & $213^{b}$ & $31.9^{b}$ & 16.2 \\
\hline & $\mathrm{AC}+\mathrm{TH} 14$ & 111 & $966^{b}$ & $28.4^{\mathrm{a}}$ & $5.56^{\mathrm{a}}$ & $185^{b}$ & $116^{\mathrm{c}}$ & $39.7^{a}$ & 16.2 \\
\hline & SEM & 4.7 & 1.4 & 0.40 & 0.490 & 4.8 & 4.4 & 1.42 & 0.01 \\
\hline & $p$ & 0.325 & 0.012 & $<0.001$ & 0.017 & $<0.001$ & $<0.001$ & 0.013 & 0.892 \\
\hline
\end{tabular}

${ }^{1}$ SCS, sweet corn stover; CSVP, cassava pulp; AC, Acremonium cellulase; TH14, L. casei strain TH14 inoculant; SEM, standard error of the means; DM, dry matter; OM, organic matter; $\mathrm{CP}$, crude protein; EE, ether extract; NDF, neutral detergent fiber; ADF, acid detergent fiber; ADL, acid detergent lignin; GE, gross energy. ${ }^{a-c}$ Means within columns with difference superscript letters differ at $p<0.05$. ${ }^{\mathrm{y}-\mathrm{z}}$ Mean separations, refer to the differences as tendencies $(p<0.10)$.

\subsection{Effect on In Vitro Digestibility of Silage}

The in vitro digestibility of SCS and CSVP silage at $24 \mathrm{~h}$ and $48 \mathrm{~h}$ incubation are presented in Table 5. After $24 \mathrm{~h}$ of incubation, the IVDMD of SCS silage ranged from 465 to $509 \mathrm{~g} \mathrm{~kg}^{-1}$ and did not differ $(p=0.18)$ among treatments, while IVNDFD and IVADFD were significantly reduced $(p<0.05)$ in the treatment with added AC+TH14. When incubation lasted $48 \mathrm{~h}$, IVDMD of SCS silage significantly increased $(p<0.05)$ with the addition of $\mathrm{AC}$ and $\mathrm{AC}+\mathrm{TH} 14$. However, the IVNDFD, and IVADFD were depressed $(p<0.05)$ by AC and AC+TH14 compared with the control and TH14. In CSVP silage, IVDMD was significantly increased $24 \mathrm{~h}$ after incubation with the addition of AC or AC + TH14 $(p<0.05)$ but this effect had disappeared $(p=0.72)$ when incubation was prolonged to $48 \mathrm{~h}$. The IVNDFD and IVADFD of CSVP silage were consistently depressed $(p<0.05)$ when AC or AC+TH14 was added compared with the control or TH14 additive.

Table 5. In vitro digestibility of silage after $60 \mathrm{~d}$ of fermentation followed by $24 \mathrm{~h}$ and $48 \mathrm{~h}$ of incubation.

\begin{tabular}{|c|c|c|c|c|c|c|c|}
\hline \multirow{2}{*}{ Item $^{1}$} & \multirow{2}{*}{ Additives } & \multicolumn{3}{|c|}{$24 \mathrm{~h}$ Incubation } & \multicolumn{3}{|c|}{$48 \mathrm{~h}$ Incubation } \\
\hline & & $\begin{array}{l}\text { IVDMD } \\
\left(\mathrm{g} \mathrm{kg}^{-1}\right)\end{array}$ & $\begin{array}{l}\text { IVNDFD } \\
\left(\mathrm{g} \mathrm{kg}^{-1}\right)\end{array}$ & $\begin{array}{l}\text { IVADFD } \\
\left(\mathrm{g} \mathrm{kg}^{-1}\right)\end{array}$ & $\begin{array}{l}\text { IVDMD } \\
\left(\mathrm{g} \mathrm{kg}^{-1}\right)\end{array}$ & $\begin{array}{l}\text { IVNDFD } \\
\left(\mathrm{g} \mathrm{kg}^{-1}\right)\end{array}$ & $\begin{array}{r}\text { IVADFD } \\
\left(\mathrm{g} \mathrm{kg}^{-1}\right)\end{array}$ \\
\hline \multirow{6}{*}{ SCS silage } & Control & 465 & $323^{a}$ & $277^{a}$ & $598^{b}$ & $538^{a}$ & $519^{a}$ \\
\hline & $\mathrm{AC}$ & 509 & $278^{a b}$ & $229^{a}$ & $630^{a}$ & $473^{b}$ & $452^{b}$ \\
\hline & TH14 & 469 & $306^{a}$ & $263^{a}$ & $610^{b}$ & $542^{a}$ & $516^{a}$ \\
\hline & $\mathrm{AC}+\mathrm{TH} 14$ & 494 & $221^{b}$ & $166^{b}$ & $626^{a}$ & $450^{b}$ & $399^{c}$ \\
\hline & SEM & 14.7 & 20.9 & 21.4 & 4.6 & 7.2 & 8.5 \\
\hline & $p$ & 0.181 & 0.038 & 0.010 & 0.004 & $<0.001$ & $<0.001$ \\
\hline \multirow{6}{*}{ CSVP silage } & Control & $847^{b}$ & $635^{a}$ & $555^{a}$ & 905 & $762^{a}$ & $676^{a}$ \\
\hline & $\mathrm{AC}$ & $892^{a}$ & $116^{\mathrm{b}}$ & $140^{b}$ & 917 & $511^{b}$ & $271^{b}$ \\
\hline & TH14 & $845^{b}$ & $620^{a}$ & $522^{a}$ & 913 & $771^{a}$ & $663^{a}$ \\
\hline & $\mathrm{AC}+\mathrm{TH} 14$ & $875^{a}$ & $155^{b}$ & $187^{b}$ & 904 & $485^{b}$ & $268^{b}$ \\
\hline & SEM & 6.3 & 26.6 & 18.4 & 9.7 & 30.6 & 18.7 \\
\hline & $p$ & 0.002 & $<0.001$ & $<0.001$ & 0.742 & $<0.001$ & $<0.001$ \\
\hline
\end{tabular}

${ }^{1}$ SCS, sweet corn stover; CSVP, cassava pulp; AC, Acremonium cellulase; TH14, L. casei strain TH14 inoculant; SEM, standard error of the means; IVDMD, in vitro dry matter digestibility; IVNDFD, in vitro neutral detergent fiber digestibility; IVADFD, in vitro acid detergent fiber digestibility. ${ }^{\mathrm{a}-\mathrm{c}}$ Means within columns with difference superscript letters differ at $p<0.05$. 


\section{Discussion}

\subsection{Microbial Population and Chemical Composition of Sweet Corn Stover and Cassava Pulp}

Microorganisms play major roles in silage-making practices, most of which use nutrients in plant materials to grow, thus altering the nutrient value of silage for livestock [29]. In this present study, the microbial numbers (Table 1) ranged within the typical populations of bacterial, yeast, and fungal groups in plants prior to ensiling [29]. For instance, the microbial counts in CSVP are in accordance with those of a previous study [6]. Among microbial strains, a high population of epiphytic LAB can improve lactic acid fermentation, which has a probiotic effect or, critically, decreases the $\mathrm{pH}$ to halt clostridial growth [29]. An optimum epiphytic LAB number in tropical grasses was revealed to be $10^{5} \mathrm{cfu} \mathrm{g}^{-1}$ FM [16]. In this study, the LAB counts of $10^{4}$ to $10^{5} \mathrm{cfu} \mathrm{g}^{-1} \mathrm{FM}$ might be adequate for obtaining good ensiling characteristics. In addition, low counts of coliform, aerobic bacteria, yeasts, and molds were found in this study. However, these strains do not effectively improve fermentation, nor do they maximize the preservation of nutrients in silage [10].

The optimal DM content for assisting fermentation and transportation of pre-ensiled materials ranged from 200 to $400 \mathrm{~g} \mathrm{~kg}^{-1}$. The DM content of the SCS and CSVP silage used in this study were slightly low (187 to $237 \mathrm{~g} \mathrm{~kg}^{-1}$ ). The DM, OM, CP, EE, NDF, and ADF contents of SCS were consistent with those reported by Gao et al. [4] and those of CSVP were consistent with those reported by Napasirth et al. [8]. The EE or lipids are 2.25 times more combustible than the other OM fractions [30]; thus, the GE content of SCS and CSVP can vary by the portions of EE content [31].

\subsection{Ensiling Characteristics}

Ensiling characteristics that are considered end-products could help to verify the appropriate methods in silage production [7]. All silage in this study was well preserved with low $\mathrm{pH}$ value (3.42-3.87) and $\mathrm{NH}_{3}-\mathrm{N}$ content, and high lactic acid content (Table 2). Having a pH level less than 4.2 is important as it inhibits harmful bacterial activities, especially clostridia. Our results suggest that the addition of either AC or TH14 can significantly decrease the $\mathrm{pH}$ of SCS and CSVP silage compared with the control. However, adding AC+TH14 did not clearly affect the pH of SCS silage. Previously, the use of AC+TH14 could have advantages over AC or TH14 alone as a positively combined effect to promote the ensiling characteristics of tropical forages [11,16]. Moreover, Gao et al. [4] reported that the $\mathrm{pH}$ of SCS silage significantly decreased when adding AC plus L. plantarum, and this effect was stronger than adding L. plantarum alone. We cannot explain the mechanism of these findings. More research is required to elucidate the probiotic mode of LAB inoculants to SCS silage.

The results imply that the addition of AC, TH14, and AC+TH14 to silage could enhance lactic acid production and support the decrease to the $\mathrm{pH}$ value. The mode of action of fibrolytic enzymes could be the degradation of fibrous fractions and supply of essential substrate (fermentable sugars) for lactic acid producing bacteria growth $[7,12]$. Thus, LAB helps enzymes to improve the ensiling characteristics by causing a sharp rate of lactic acid fermentation [18]. Although improved lactic acid production in SCS silage supports the previous findings of Gao et al. [4], the results we obtained for CSVP silage were not consistent with those of LAB inoculants reported in Napasirth et al. [8]. Napasirth et al. [8] found that it is difficult to increase lactic acid production in CSVP silage with LAB inoculants because of high epiphytic LAB numbers, especially homofermentative strains. Khota et al. [16] reported that L. plantarum and L. casei (homofermentative rods) could be the dominant species in tropical silage. In the present study, an insufficient number of homofermentative LAB naturally present on fresh CSVP might lead to increase lactic acid production in CSVP silage prepared with TH14 in comparison to control. In facts, many factors (i.e., sources, seasons, preparation methods and etc.) control the characteristics of the epiphytic LAB in CSVP. This finding suggests that TH14 inoculant is an effective additive to ensure the fermentation quality of CSVP silage when the microbial profile might 
be not appropriate. However, more research is needed to evaluate microbial community and dynamic fermentation in CSVP silage.

The results found that acetic acid production in SCS silage increased but in CSVP silage it decreased when the additive was AC+TH14. Moreover, the results showed very high level of acetic acid, especially in CSVP silage, where in treated silage the proportion of acetic acid to lactic acid is over $50 \%$ and in control silage its content is higher than lactic acid. Acetic acid production might help to enhance the aerobic stability of silage [7]. However, in good quality silage the content of acetic acid should not to be higher than $10-20 \%$. Pholsen et al. [18] suggested that abundant acetic acid fermentation could occur during ensiling with heterofermentative LAB species. Therefore, the variation in the final acetic acid levels among types of silage may have been related to the population of epiphytic LAB present. In this study, only a tend $(p<0.10)$ was noted for the difference of propionic acid and butyric acid results among silage additive treatments. The concentration of these acids in silage is usually low [7,32]. Chen et al. [33] indicated that increased propionic acid content might inhibit lactic acid production of silage, provide more residual sugar, and prolong aerobic stability. The $\mathrm{NH}_{3}-\mathrm{N}$ content are a good indicator of proteolysis in silage [7]. It can indicate a reduction in the biological value of CP content, as comparatively lower values of $\mathrm{NH}_{3}-\mathrm{N}$ were evident among various dietary nitrogenous compounds [34]. Thus, the addition of AC could be recommended for improving the silage quality of SCS in this work.

\subsection{Microbial Population of Silage}

Undesirable microorganisms in silage, such as aerobic bacteria, yeasts, and molds, are detrimental to the nutritional quality of silage when oxygen is available [10]. In this experiment, the variation in microbial counts of silage (Table 3) was probably related to the reduction in $\mathrm{pH}$, the main factor that affects silage microbes with high resistance to acidic conditions. The significantly higher $(p<0.05)$ aerobic bacteria population we found in SCS silage with the addition of $\mathrm{AC}+\mathrm{TH} 14$ was a surprising result. This means that some aerobic bacteria can survive low- $\mathrm{pH}$ conditions in silage of various materials and with microbial ecology stimulation of AC+TH14. This result is contrary to a previous finding [17] and the reason for this is not clear. Perhaps the aerobic spore-containing bacilli can grow in a relatively low $\mathrm{pH}$ environment such as that of silage. Future studies are needed to explore the relationship between spore-forming aerobic bacteria and silage fermentation.

\subsection{Chemical Composition and Gross Energy Content of Silage}

The chemical composition and GE content of silage determine the nutritive value for livestock [34]. Our results confirm those of previous reports [4,11,16,35], in which additives changed the chemical composition and GE content of silage (Table 4). Khota et al. [16] indicated that about $2 \%$ of DM content can disappear with the effects of additives. Here, OM content was decreased when AC or AC+TH14 was added to CSVP silage, unlike when it was added to SCS silage. The addition of $\mathrm{AC}$ or $\mathrm{AC}+\mathrm{TH} 14$ increased the $\mathrm{CP}$ content and led to a significant decrease in the NDF content of silage. Moreover, there was reduced ADF content in silage when any additive was used.

The delignification of TH14 in CSVP silage was surprising. This finding is in contrast to that of Li et al. [15], in which the AC+TH14 did not alter the ADL content. LAB are unable to decompose plant fiber and lignin directly $[17,18]$, so perhaps other fiber-decomposing microbes that degrade fiber and lignin during silage fermentation could be found, which might be the cause of a reduction in fibrous contents and delignification in the silage. Most plant feedstuffs are able to combust at 15.0 to $20.0 \mathrm{MJ} \mathrm{GE} \mathrm{kg}{ }^{-1} \mathrm{DM}$ [31]. In this study, the results show the GE content of SCS silage could be slightly decreased by either AC or TH14.

\subsection{In Vitro Digestibility of Silage}

In vitro experiments are an important research step used to determine whether to apply potential treatments to animals [34]. In ruminants, the IVDMD in rumen fluid is 
primarily responsible for estimating energy partition potential in feedstuffs [23]. Therefore, the comparison of silage quality with IVDMD has practical relevance for the estimation of feed utilization [12]. In this study, improved IVDMD was found from both SCS and CSVP silage, which were prepared with AC and AC+TH14 (Table 5). However, the TH14 did not improve the IVDMD of silage in this study. Thus, the positive effects should be archived from the enzymatic saccharification of AC at ensiling, as AC increases the ruminal fermentable fractions of silage. This finding is in agreement with that of Rinne et al. [35], who demonstrated that an optimized enzymatic saccharification using cellulase helps to satiate lactic acid fermentation during ensiling and increases the in vitro OM digestibility of the silage.

In comparison to the control, adding $\mathrm{AC}$ or $\mathrm{AC}+\mathrm{TH} 14$ significantly depressed the IVNDFD and IVADFD of SCS and CSVP silage. This lower ruminal fiber digestibility probably resulted from a high lignin-fiber condensation. Fibrous fractions of silage could partially be degraded by AC and the escaped portions should be condensed by lignin. This plant composition is complex and can protect the accessibility of ruminal enzymatic activities in hydrolyzing hemicellulose and cellulose [34].

The results evaluate that the level of IVDMD in SCS silage could be lower than in CSVP silage. This is related to the differences in carbohydrate type between SCS and CSVP (NDF vs. NFC sources). As the IVDMD of CSVP was extremely high $\left(>845 \mathrm{~g} \mathrm{~kg}^{-1}\right)$, an enhanced IVDMD could be offset when the incubation was prolonged to $48 \mathrm{~h}$.

\section{Conclusions}

The results of this study suggest that the addition of $\mathrm{AC}\left(0.1 \mathrm{~g} \mathrm{~kg}^{-1} \mathrm{FM}\right)$ could help to improve ensiling characteristics ( $\mathrm{pH}$ value, lactic acid production, and $\mathrm{NH}_{3}-\mathrm{N}$ content), the chemical composition (CP and fiber contents), and IVDMD of SCS and CSVP silage. The addition of $L$. casei strain TH14 $\left(10^{8} \mathrm{cfu} \mathrm{kg}^{-1} \mathrm{FM}\right)$ enhanced the lactic acid fermentation of silage, but in combination with its enzymatic application (AC+TH14) it could not decrease the $\mathrm{NH}_{3}-\mathrm{N}$ content in SCS silage. To capture the benefits to silage quality of ensiling SCS and CSVP with AC, TH14, or AC+TH14, an in vivo evaluation in ruminant livestock will need to be conducted.

Author Contributions: Conceptualization, C.K., W.K., and A.C.; formal analysis, S.T.-u., C.K., and W.K.; investigation, C.K., and W.K.; resources, C.K., W.K., and A.C.; writing-original draft preparation, W.K.; writing-review and editing, C.K., S.T.-u., W.K., and A.C.; supervision, C.K., and W.K.; funding acquisition, A.C., W.K., and C.K. All authors have read and agreed to the published version of the manuscript.

Funding: This research was funded in partial by the National Research Council of Thailand (NRCT), grant number 572103, and by the Increase Production Efficiency and Meat Quality of Native Beef and Buffalo Research Group (Khon Kaen University). The APC was funded by Khon Kaen University.

Institutional Review Board Statement: The study was conducted according to the guidelines of the Declaration of Helsinki, and approved by the Animal Ethics Committee of Faculty of Natural Resources, Rajamangala University of Technology Isan (approval number 5321/217 on 28th October 2020).

Informed Consent Statement: None.

Data Availability Statement: None.

Acknowledgments: The authors would like to thank Yimin Cai (Japan International Research Center for Agricultural Sciences, Japan) for technical support. The authors thank Rajamangala University of Technology Isan, Animal Nutrition Laboratory (Khon Kaen University), and Japan International Research Center for Agricultural Sciences for the infrastructure and laboratory facilities.

Conflicts of Interest: The authors declare no conflict of interest. The funders had no role in the design of the study; in the collection, analyses, or interpretation of data; in the writing of the manuscript, or in the decision to publish the results. 


\section{References}

1. Serrapica, F.; Masucci, F.; Raffrenato, E.; Sannino, M.; Vastolo, A.; Barone, C.M.A.; Di Francia, A. High fiber cakes from Mediterranean multipurpose oilseeds as protein sources for ruminants. Animals 2019, 9, 918. [CrossRef] [PubMed]

2. The Working Committee of Thai Feeding Standard for Ruminant (WTSR). Nutrient Requirement of Beef Cattle in Indochinese Peninsula; Klungnanavitthaya Press: Khon Kaen, Thailand, 2010.

3. Office of Agricultural Economics (OAE) Database. Available online: http:/ / www.oae.go.th (accessed on 8 December 2020).

4. Gao, J.L.; Wang, P.; Zhou, C.H.; Li, P.; Tang, H.Y.; Zhang, J.B.; Cai, Y. Chemical composition and in vitro digestibility of corn stover during field exposure and the fermentation characteristics of silage prepared with microbial additives. Asian Australas. J. Anim. Sci. 2019, 32, 1854-1863. [CrossRef] [PubMed]

5. Kosugi, A.; Kondo, A.; Ueda, M.; Murata, Y.; Vaithanomsat, P.; Thanapase, W.; Arai, T.; Mori, Y. Production of ethanol from cassava pulp via fermentation with a surface-engineered yeast strain displaying glucoamylase. Renew. Energy 2009, 34, 1354-1358. [CrossRef]

6. Keaokliang, O.; Kawashima, T.; Angthong, W.; Suzuki, T.; Narmseelee, R. Chemical composition and nutritive values of cassava pulp for cattle. Anim. Sci. 2018, 89, 1120-1128. [CrossRef] [PubMed]

7. McDonald, P.; Henderson, A.; Heron, S. The Biochemistry of Silage; Chalcombe Publications: Marlow, UK, 1991.

8. Napasirth, V.; Napasirth, P.; Sulinthone, T.; Phommachanh, K.; Cai, Y. Microbial population, chemical composition and silage fermentation of cassava residues. Anim. Sci. J. 2015, 86, 842-848. [CrossRef] [PubMed]

9. Chen, K.; Li, J.; Ma, J.; Jiang, M.; Wei, P.; Liu, Z.; Ying, H. Succinic acid production by Actinobacillus succinogenes using hydrolysates of spent yeast cells and corn fiber. Bioresour. Technol. 2011, 102, 1704-1708. [CrossRef] [PubMed]

10. Driehuis, F.; Wilkinson, J.M.; Jiang, Y.; Ogunade, I.; Adesogan, A.T. Silage review: Animal and human health risks from silage. J. Dairy Sci. 2018, 101, 4093-4110. [CrossRef]

11. Khota, W.; Pholsen, S.; Higgs, D.; Cai, Y. Comparative analysis of silage fermentation and in vitro digestibility of tropical grass prepared with Acremonium and Tricoderma species producing cellulases. Asian Australas. J. Anim. Sci. 2018, 31, 1913-1922. [CrossRef]

12. Kaewpila, C.; Khota, W.; Gunun, P.; Kesorn, P.; Cherdthong, A. Strategic addition of different additives to improve silage fermentation, aerobic stability and in vitro digestibility of Napier grasses at late maturity stage. Agriculture 2020, 10, 262. [CrossRef]

13. Silva, V.P.; Pereira, O.G.; Leandro, E.S.; Paula, R.A.; Agarussi, M.C.N.; Ribeiro, K.G. Selection of lactic acid bacteria from alfalfa silage and its effects as inoculant on silage fermentation. Agriculture 2020, 10, 518. [CrossRef]

14. Kuppusamy, P.; Kim, D.; Soundharrajan, I.; Park, H.S.; Jung, J.S.; Yang, S.H.; Choi, K.C. Low-carbohydrate tolerant LAB strains identified from rumen fluid: Investigation of probiotic activity and legume silage fermentation. Microorganisms 2020, 8, 1044. [CrossRef] [PubMed]

15. Li, F.; Ke, W.; Ding, Z.; Bai, J.; Zhang, Y.; Xu, D.; Li, Z.; Guo, X. Pretreatment of Pennisetum sinese silages with ferulic acid esterase-producing lactic acid bacteria and cellulase at two dry matter contents: Fermentation characteristics, carbohydrates composition and enzymatic saccharification. Bioresour. Technol. 2020, 295, 122261. [CrossRef] [PubMed]

16. Khota, W.; Pholsen, S.; Higgs, D.; Cai, Y. Natural lactic acid bacteria population of tropical grasses and their fermentation factor analysis of silage prepared with cellulase and inoculant. J. Dairy Sci. 2016, 99, 9768-9781. [CrossRef] [PubMed]

17. Khota, W.; Pholsen, S.; Higgs, D.; Cai, Y. Fermentation quality and in vitro methane production of sorghum silage prepared with cellulase and lactic acid bacteria. Asian Australas. J. Anim. Sci. 2017, 30, 1568-1574. [CrossRef]

18. Pholsen, S.; Khota, W.; Pang, H.; Higgs, D.; Cai, Y. Characterization and application of lactic acid bacteria for tropical silage preparation. Anim. Sci. J. 2016, 87, 1202-1211. [CrossRef] [PubMed]

19. Kung, L.J. Silage Fermentation \& Additives; Miller Publishing Co.: Minnetonka, MN, USA, 2001.

20. Kozaki, M.; Uchimura, T.; Okada, S. Experimental Manual for Lactic Acid Bacteria; Asakurasyoten: Tokyo, Japan, 1992.

21. Association of Official Analytical Chemists (AOAC). Official Methods of Analysis, 15th ed.; Association of Official Analytical Chemists: Arlington, VA, USA, 1990.

22. Faichney, G.; White, G. Methods for the Analysis of Feeds Eaten by Ruminants; Division of Animal Production, Ian Clunies Ross Animal Research Laboratory, Commonwealth Scientific and Industrial Research Organization: Melbourne, Australia, 1983.

23. Mertens, D.R. Creating a system for meeting the fiber requirements of dairy cows. J. Dairy Sci. 1997, 80, 1463-1481. [CrossRef]

24. Cai, Y.; Benno, Y.; Ogawa, M.; Kumai, S. Effect of applying lactic acid bacteria isolated from forage crops on fermentation characteristics and aerobic deterioration of silage. J. Dairy Sci. 1999, 82, 520-526. [CrossRef]

25. Porter, M.G.; Murray, R.S. The volatility of components of grass silage on oven drying and the inter-relationship between dry-matter content estimated by different analytical methods. Grass Forage Sci. 2001, 56, 405-411. [CrossRef]

26. Fawcett, J.K.; Scott, J.E. A rapid and precise method for the determination of urea. J. Clin. Pathol. 1960, 13, 156-159. [CrossRef]

27. Makkar, H.P.; Blümmel, M.; Becker, K. Formation of complexes between polyvinyl pyrrolidones or polyethylene glycols and tannins, and their implication in gas production and true digestibility in in vitro techniques. Br. J. Nutr. 1995, 73, 897-913. [CrossRef]

28. Steel, R.G.D.; Torrie, J.H. Principles and Procedures of Statistics: A Biometrical Approach, 2nd ed.; McGraw-Hill Book Co. Inc.: New York, NY, USA, 1980.

29. Muck, R.E. Silage microbiology and its control through additives. Rev. Bras. Zootec. 2010, 39, 183-191. [CrossRef] 
30. Agricultural Research Council (ARC). Nutrient Requirements of Ruminant Livestock; Commonwealth Agricultural Bureau: London, UK, 1984.

31. Kaewpila, C.; Sommart, K. Development of methane conversion factor models for Zebu beef cattle fed low-quality crop residues and by-products in tropical regions. Ecol. Evol. 2016, 6, 7422-7432. [CrossRef] [PubMed]

32. Higginbotham, G.E.; Depeters, E.J.; Mueller, S.C. Effect of propionic acid producing bacteria on corn silage fermentation. Prof. Anim. Sci. 1996, 12, 176-180. [CrossRef]

33. Chen, L.; Guo, G.; Yuan, X.; Shimojo, M.; Yu, C.; Shao, T. Effect of applying molasses and propionic acid on fermentation quality and aerobic stability of total mixed ration silage prepared with whole-plant corn in Tibet. Asian Australas. J. Anim. Sci. 2014, 27, 349-356. [CrossRef]

34. Van Soest, P.J. Nutritional Ecology of the Ruminant, 2nd ed.; Cornell University Press: Ithaca, NY, USA, 1994.

35. Rinne, M.; Winquist, E.; Pihlajaniemi, V.; Niemi, P.; Seppälä, A.; Siika-aho, M. Fibrolytic enzyme treatment prior to ensiling increased press-juice and crude protein yield from grass silage. Bioresour. Technol. 2020, 299, 122572. [CrossRef] 